\title{
Purification, kinetics and spectral characterisation of a new versatile peroxidase from a Bjerkandera sp. isolate
}

\author{
Patrícia R. Moreira ${ }^{a, b}$, F. Bouillenne ${ }^{c}$, E. Almeida-Vara ${ }^{a}$, \\ F. Xavier Malcata ${ }^{b}$, J.M. Frère $^{\mathrm{c}}$, J. Cardoso Duarte $^{\mathrm{a}, *}$ \\ ${ }^{a}$ Departamento de Biotecnologia, Instituto National de Engenharia, Tecnologia e Inovação (INETI), Est. Paço do Lumiar 22, P-1649-038 Lisboa, Portugal \\ ${ }^{\mathrm{b}}$ Escola Superior de Biotecnologia, Universidade Católica Portuguesa, R. Dr. António Bernardino de Almeida, P-4200-072 Porto, Portugal \\ ${ }^{\mathrm{c}}$ Centre d'Ingénierie des Protéines, Université de Liège, Institut de Chimie, B6 Sart Tilman, B-4000 Liège, Belgique
}

Keywords: Enzyme; Oxidoreductase; White-rot fungus

\begin{abstract}
From the extracellular fluid of a novel strain of Bjerkandera sp., it was isolated, purified and identified the main enzyme responsible for Remazol Brilliant Blue R dye decolourisation. Such an enzyme is able to oxidise manganese, as well as veratryl alcohol and 2,6dimethoxyphenol in manganese-independent reactions; hence, it can be included in the new group of versatile peroxidases. The molecular mass of said enzyme is ca. $45 \mathrm{kDa}$, and the N-terminal amino acid sequence obtained by Edman degradation is VAXPDGVNTA. The enzyme substrate range for oxidation of several phenolic and non-phenolic aromatic compounds was determined and the corresponding Michaelis-Menten kinetic constants calculated. Furthermore, spectrophotometric assays showing the Soret band and allowing observation of band shifts of the enzyme led to the conclusion that Bjerkandera strains may also synthesise at least two different versatile peroxidases, as happens with Pleurotus eryngii.
\end{abstract}

\section{Introduction}

During the last decade, research on the lignin-degradation ability of fungi has focused mainly on basidiomycetes commonly known as white-rot fungi. The complexity of the lignin attack mechanisms-which involve a number of different enzymes, the relative importance of which depends on the fungus considered, reveals the importance of the search for novel fungal isolates as a potential source of new enzymes with improved performances considering kinetics and substrate specificity.

Among those studies attention has recently been paid to a novel class of ligninolytic peroxidases, with high affinity for manganese and dyes; these enzymes can also oxidise 2,6-dimethoxyphenol (DMP) and veratryl alcohol (VA) in a manganese-independent reaction, hence combining typical

\footnotetext{
* Corresponding author. Fax: +351 217163636 .

E-mail address: jose.duarte@ineti.pt (J.C. Duarte).
}

properties of both $\mathrm{MnP}$ and LiP enzymes - coupled with a broad substrate range. Another unique feature of these versatile peroxidases (VP) is that they do not require mediators for substrate oxidation, including decolourisation of several dyes - a fact that could be of potential interest in many industrial biotechnological applications. Until now, versatile peroxidase enzymes have been isolated only from a few species: Pleurotus ostreatus, Pleurotus eryngii, Bjerkandera adusta and Bjerkandera sp. strain BOS55 [1-9].

Not surprisingly, the search for new ligninolytic fungal strains exhibiting high decolourisation activity on Poly R-478 and Remazol Brilliant Blue R (RBBR) dyes, revealed a new type of Bjerkandera sp. strain B33/3 [10]. Analyses of peroxidase activities in the extracellular fluid of this strain demonstrated the existence of lignin peroxidase, as well as manganese-dependent and manganese-independent peroxidase activities. In such a strain, RBBR decolourisation occurs via an enzyme-mediated process, which depends on the presence of hydrogen peroxide in the reaction medium. 
For further elucidation of the mechanism of decolourisation it was important to isolate, purify and characterise the peroxidase which was mainly responsible for the RBBR dye decolourising activity of this new Bjerkandera $\mathrm{sp.}$

\section{Materials and methods}

\section{Culture conditions and enzyme purification}

Bjerkandera sp. strain B33/3 was grown in CDBYE medium, as described elsewhere [10]. The extracellular fluid of a 5.5-L culture was separated from the mycelium by filtration through Whatman no. 1 filter paper (from Millipore).

The proteins extracted from that clear extracellular fluid were adsorbed on Q-Sepharose Fast Flow (Pharmacia); elution afterwards was by $10 \mathrm{mM} \mathrm{Na}$ cacodylate buffer $(\mathrm{pH}$ $6.0)$, using a linear gradient of $\mathrm{NaCl}(0-0.6 \mathrm{M})$; further concentration was provided by ultrafiltration with an Amicon YM 10 membrane (10 kDa MW cut-off), followed by dialysis overnight against $10 \mathrm{mM}$ cacodylate buffer $(\mathrm{pH}$ 6.0). The concentrated fractions were applied on a G-100 gel filtration column (Pharmacia), and eluted once again with the aforementioned buffer.

Pooled fractions possessing dye decolourising activity were then applied onto a Q-Sepharose Fast Flow column (Pharmacia), and eluted by $20 \mathrm{mM}$ sodium tartrate buffer $(\mathrm{pH}$ $5.0)$ using a linear gradient of $\mathrm{NaCl}(0-0.4 \mathrm{M})$. The fractions of interest were concentrated by ultraflitration with an Amicon YM 10 membrane (10 kDa MW cut-off), and dialysed overnight against $10 \mathrm{mM}$ cacodylate buffer ( $\mathrm{pH}$ 6.0).

The fractions, thus obtained were further resolved by ion exchange chromatography on a Mono Q column (type $\mathrm{HR}$ /5, from Pharmacia), using a 0-0.4 M linear gradient of $\mathrm{NaCl}$, with an Akta FPLC system (Amersham-Pharmacia Biotech). The pooled fractions were once again concentrated, dialysed overnight against $10 \mathrm{mM}$ cacodylate buffer ( $\mathrm{pH}$ 6.0), and stored at $4{ }^{\circ} \mathrm{C}$ before enzymatic assays were in order.

\section{Enzyme activity characterisation}

The activity of manganese peroxidase (MnP, EC 1.11.1.13) was determined using 3-methyl-2-benzithiazolinone hydrazone (MBTH) and dimethylaminobenzoic acid (DMAB) as substrates, following the method by Castillo et al. [11]. The manganese-independent peroxidase (MiP) activity was estimated using DMP as substrate, according to Mester and Field [12]. The activity of lignin-peroxidase (LiP, EC 1.11.1.14) was determined using VA as substrate, following the procedures reported by Linko and Haapala [13]. The RBBR decolourising activity was assayed spectrophotometrically by measuring the decrease in absorbance at $595 \mathrm{~nm}$ $\left(30{ }^{\circ} \mathrm{C}\right)$, as described elsewhere [10]. The $\mathrm{Mn}(\mathrm{II})$ activity was assayed spectrophotometrically by measuring the decrease in absorbance at $238 \mathrm{~nm}\left(30^{\circ} \mathrm{C}\right)$ [3]. The enzymatic standard

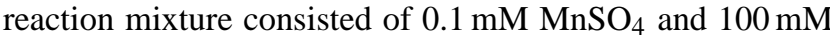

sodium tartrate buffer $(\mathrm{pH} 5.0)$; the reaction was initiated via addition of $0.1 \mathrm{mM} \mathrm{H} \mathrm{H}_{2} \mathrm{O}_{2} \quad\left(\varepsilon_{238}=6500 \mathrm{M}^{-1} \mathrm{~cm}^{-1}\right)$. The 2,2'-azinobis(3-ethylbenzothiazolme-6-sulphonic acid) (ABTS) oxidising activity was assayed spectrophotometrically by measuring the decrease in absorbance at $420 \mathrm{~nm}$ $\left(25^{\circ} \mathrm{C}\right)$ [14]. The standard reaction mixture consisted of $0.5 \mathrm{mM}$ ABTS and $100 \mathrm{mM}$ sodium tartrate buffer $(\mathrm{pH} 4.5)$. The reaction was initiated via addition of $0.1 \mathrm{mM} \mathrm{H}_{2} \mathrm{O}_{2}$ $\left(\varepsilon_{420}=36,000 \mathrm{M}^{-1} \mathrm{~cm}^{-1}\right)$. Kinetic constants for selected substrates in $100 \mathrm{mM}$ sodium tartrate, at $\mathrm{pH}$ 3.0, 3.5 and 5.0, were derived from the linear phases of reaction. Activities were calculated from the molar absorbance of the reaction products produced from catechol $\left(\varepsilon_{238}=6500 \mathrm{M}^{-1} \mathrm{~cm}^{-1}\right)$, hydroquinone $\left(\varepsilon_{247}=21,000 \mathrm{M}^{-1} \mathrm{~cm}^{-1}\right)$, 4-methoxyphenol $\left(\varepsilon_{253}=4990 \mathrm{M}^{-1} \mathrm{~cm}^{-1}\right)$, methylhydroquinone $\quad\left(\varepsilon_{250}=\right.$ $\left.21,120 \mathrm{M}^{-1} \mathrm{~cm}^{-1}\right), \quad p$-aminophenol $\quad\left(\varepsilon_{246}=15,627 \mathrm{M}^{-1}\right.$ $\left.\mathrm{cm}^{-1}\right)$, guaiacol $\left(\varepsilon_{456}=12,100 \mathrm{M}^{-1} \mathrm{~cm}^{-1}\right)$, ferulic acid $\left(\varepsilon_{310}=8680 \mathrm{M}^{-1} \mathrm{~cm}^{-1}\right), \alpha-\operatorname{naftol}\left(\varepsilon_{255}=12,800 \mathrm{M}^{-1} \mathrm{~cm}^{-1}\right)$ and Reactive Black $5\left(\varepsilon_{598}=50,000 \mathrm{M}^{-1} \mathrm{~cm}^{-1}\right)$. The physicochemical data were from Heinfling et al. [1]. Apparent $K_{\mathrm{m}}$ and $V_{\max }$ values were estimated from Hanes plots.

The $\mathrm{pH}$ dependence and stability of the enzyme in terms of substrate oxidation reaction were measured under standard assay conditions, using $100 \mathrm{mM}$ sodium tartrate buffer. All assays were performed in triplicate; the data values considered hereafter are means of the replicates that exhibit a standard error below $10 \%$.

\section{Proteinaceous feature determination}

During the sequential purification steps, the protein concentration was estimated spectrophotometrically at $280 \mathrm{~nm}$. The final protein concentration of the fractions with interest was also determined via Bradford Protein Assay (Bio-Rad), using bovine serum albumin (Fluka) as standard.

Sodium dodecyl sulfate (SDS)-polyacrylamide gel electrophoresis of $20 \mu \mathrm{g}$ of the native protein was performed in a $10 \%(\mathrm{w} / \mathrm{w})$ polyacrylamide gel, and protein bands were stained with Coomassie Blue R-250. For molecular weight determination, the gels were calibrated using the $10 \mathrm{kDa}$ protein ladder (Gibco BRL) as standard.

The N-terminal sequence of the mature peroxidase was obtained by automated Edman degradation of ca. $5 \mu \mathrm{g}$ of protein, using a Procise Protein Sequencing System (Applied Biosystems).

\section{Spectral characterisation}

Purified protein $\left(0.08 \mathrm{~g} \mathrm{~L}^{-1}\right)$ in $10 \mathrm{mM}$ cacodylate buffer ( $\mathrm{pH}$ 6.0) was spectrophotometrically scanned from $300 \mathrm{up}$ to $700 \mathrm{~nm}$, so as to identify the Soret band; $\mathrm{H}_{2} \mathrm{O}_{2}(0.4 \mathrm{mM}$, 230 molar equivalents) was then added to oxidise the enzyme and hence allow observation of the corresponding band shifts. 
Table 1

Comparison of N-terminal sequences of RBP with those encoding novel versatile peroxidases recently described for other strains

\begin{tabular}{|c|c|c|c|}
\hline Strain & Enzyme & N-terminal sequence & Reference \\
\hline Bjerkandera sp. B33/3 & RBP & VAXPDGVNTA & This work \\
\hline Bjerkandera sp. BOS55 & Mnp-LiP hybrid & VACEPDGVNTATNAACCALFAVRDDI & {$[2]$} \\
\hline Bjerkandera sp. BOS55 & $\begin{array}{l}\text { BOS1 } \\
\text { BOS2 }\end{array}$ & $\begin{array}{l}\text { VAXPDGVNTATNAAXXXLFAVRDDI } \\
\text { VAXPDGVNTATNAAXXALFAVRDDI }\end{array}$ & [5] \\
\hline Bjerkandera adusta DSM11310 & $\mathrm{MnP1}$ & VAXPDGVNTATNAAXXALFAVRDDI & {$[1]$} \\
\hline Bjerkandera adusta UAMH8258 & $\mathrm{MnP}$ & VAXPDGVNTATNAAXXALFA & {$[22]$} \\
\hline Pleurotus ostreatus & $\mathrm{MnP} 2$ & VTCEATGQTTANEACCALFPILED & {$[23]$} \\
\hline Pleurotus eryngii & $\begin{array}{l}\text { MnPL1 } \\
\text { MnPL2 }\end{array}$ & $\begin{array}{l}\text { ATCEDDGRTTA-NAACCILFPILDDI } \\
\text { ATCEADGRTTA-NAACCVLFPILDDI }\end{array}$ & [9] \\
\hline Pleurotus eryngii & $\begin{array}{l}\text { PS1 } \\
\text { PS3 }\end{array}$ & $\begin{array}{l}\text { VTCAATGQTTANEAXXALFPI } \\
\text { VTCEADGNTV }\end{array}$ & [7] \\
\hline
\end{tabular}

Note: Mismatches are denoted in bold, undetermined are denoted in underlined.

\section{Results}

\section{Enzyme features}

The efficiency of the purification steps was monitored by the RBBR dye-decolourising activity. The aforementioned activity pertaining to the extracellular fluid from a $5.5-\mathrm{L}$ culture was $254 \mathrm{IU}$, and the associated specific activity was $5.4 \times 10^{-3} \mathrm{IU} \mathrm{mg}^{-1}$. One unit of enzyme activity (IU) was defined as the amount of enzyme that transforms $1 \mu \mathrm{mol}$ of RBBR per minute.

Several peaks were obtained following resolution by Mono-Q ion exchange chromatography, which were characterised by distinct enzyme activities; fractions were collected and divided into four main pools, according to their RBBR decolourising activity and ligninolytic activity detected. One of the pools was found to contain a pure protein with high RBBR decolourising activity - as it produced a single band in SDS-PAGE (Fig. 1). This enzyme will hereafter be denoted as RBP (RBBR Bjerkandera Peroxidase), for short. Its RBBR decolourising and ligninolytic specific activities were: $11 \mathrm{IU} \mathrm{mg}^{-1}$, for the RBBR decolourising activity; $12 \mathrm{IU} \mathrm{mg}^{-1}$, for the LiP activity; $8.7^{1}$ and $16^{2} \mathrm{IU} \mathrm{mg}^{-1}$, for the MnP activity and 3.7 IU.mg ${ }^{-1}$, for the MIP activity ( $1 \mathrm{IU}=16.67 \mathrm{nKatal})$. The RBP exhibited also properties characteristic of the novel class of peroxidases that are able to oxidise manganese, as well as VA and DMP in manganeseindependent reactions.

The molecular mass of RBP, estimated by $10 \%$ SDSPAGE, was ca. $45 \mathrm{kDa}$ (Fig. 1). The N-terminal amino acid sequence of RBP was VAXPDGVNTA. Comparison of the $\mathrm{N}$-terminal sequence of said enzyme with those encoding other versatile peroxidases, shown in Table 1, reveals striking similarities, especially with regard to those enzymes obtained from Bjerkandera sp.

\footnotetext{
1 Specific activity for MnP, calculated using MBTH/DMAB as substrates.

2 Specific activity for MnP, calculated using DMP as substrate.
}

The absorption spectrum of the RBP protein exhibits a large Soret band at $407 \mathrm{~nm}$, and two small peaks at 498 and $640 \mathrm{~nm}$, which are indicative of a heme protein (Fig. 2). The $A_{407} / A_{280}(\mathrm{RZ})$ value-which reflects the purity and spectral characteristics of the purified enzyme, was ca. 3.2 in $10 \mathrm{mM}$ cacodylate buffer ( $\mathrm{pH}$ 6.0). The estimated molar extinction coefficient at $407 \mathrm{~nm}$ was ca. $203 \mathrm{mM}^{-1} \mathrm{~cm}^{-1}$.

When hydrogen peroxide (225 molar equivalents) was added to the enzyme, the peak at $407 \mathrm{~nm}$ became broader and smaller, the peak at $498 \mathrm{~nm}$ shifted to $550 \mathrm{~nm}$ and the peak at $640 \mathrm{~nm}$ shifted to $655 \mathrm{~nm}$. The $A_{407} / A_{280}$ value changed to 1.3 .

\section{Enzyme kinetics}

The effect of $\mathrm{pH}$ upon RBBR and DMP oxidation activities was duly studied. The optimum $\mathrm{pH}$ for RBBR oxidation was ca. 4.0 in $100 \mathrm{mM}$ sodium tartrate buffer. The optimum

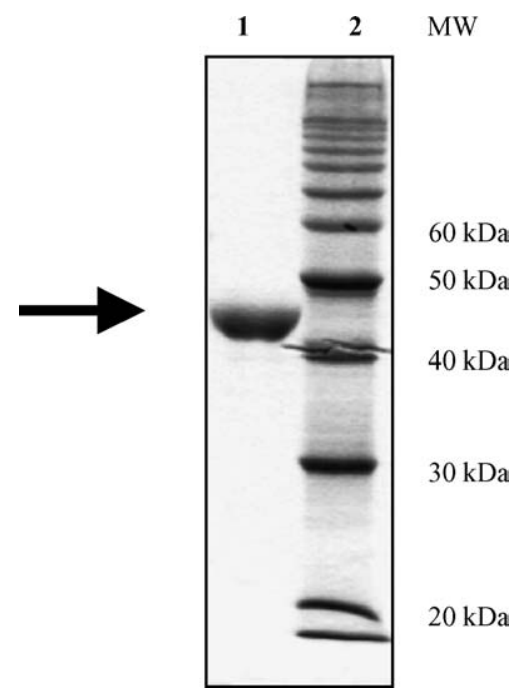

Fig. 1. SDS-PAGE electrophoregram of RBP. Lane 1, purified enzyme (indicated by an arrow) and lane 2, standard molecular weight markers. 


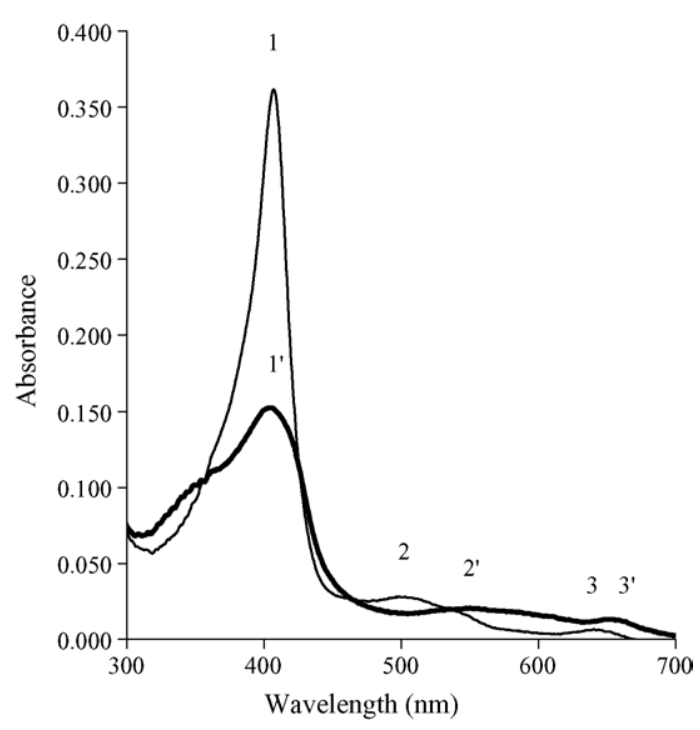

Fig. 2. Absorption spectrum of plain purified RBP $10 \mathrm{mM}$ cacodylate buffer ( $\mathrm{pH}$ 6.0) (-), and of RBP after addition of $0.4 \mathrm{mM}$ hydrogen peroxide (); 1, 2 and 3 denote major peaks in plain RBP; $1^{\prime}, 2^{\prime}$ and $3^{\prime}$ denote major peaks in RBP after addition of hydrogen peroxide.

$\mathrm{pH}$ range for oxidation of DMP in the presence of $\mathrm{Mn}$ (II) was between 4.5 and 5.0 on the same buffer. In the absence of $\mathrm{Mn}(\mathrm{II})$, but in the presence of EDTA (a chelating agent thereof), the optimum $\mathrm{pH}$ range was 3.0-3.5.

The stability of RBP, at various $\mathrm{pH}$ values, was studied as the oxidation activity on RBBR and DMP remaining after overnight incubation at $4{ }^{\circ} \mathrm{C}$ in $100 \mathrm{mM}$ sodium tartrate buffer ( $\mathrm{pH}$ range 2.0-5.5). For both substrates, the enzyme was stable at $\mathrm{pH}$ values above 3.5 .

In order to ascertain the substrate specificity of this enzyme, the oxidation abilities towards a variety of potential substrates-including the aforementioned two dyes, were determined (Tables 2 and 3). RBP was able to oxidise all compounds tested, hence confirming its high versatility and broad specificity. RBP was also able to

Table 2

Kinetic constants for RBP oxidation of selected substrates

\begin{tabular}{lrrc}
\hline Substrate & $\mathrm{pH}$ & \multicolumn{1}{c}{$\begin{array}{c}K_{\mathrm{m}} \\
(\mu \mathrm{M})\end{array}$} & $\begin{array}{c}V_{\max } \\
\left(\mathrm{IU} \mathrm{mg}^{-1}\right)\end{array}$ \\
\hline $\mathrm{H}_{2} \mathrm{O}_{2}(0.1 \mathrm{mM}$ Mn(II)) & 5.0 & 7 & 250 \\
$\mathrm{H}_{2} \mathrm{O}_{2}(0.05 \mathrm{mM}$ RBBR $)$ & 5.0 & 3 & 25 \\
$\mathrm{H}_{2} \mathrm{O}_{2}(1.0 \mathrm{mM}$ DMP; $1.0 \mathrm{mM}$ EDTA $)$ & 3.0 & 72 & 25 \\
$\mathrm{H}_{2} \mathrm{O}_{2}(05 \mathrm{mM}$ VA) & 3.0 & 182 & 28 \\
$\mathrm{Mn}(\mathrm{II})$ & 5.0 & 86 & 4 \\
$\mathrm{Mn}(\mathrm{II})(1.0 \mathrm{mM}$ DMP) & 5.0 & 55 & 125 \\
DMP (1.0 mM Mn(II)) & 5.0 & 23 & 83 \\
DMP (1.0 mM EDTA) & 5.0 & 100 & 13 \\
DMP(1.0 mM Mn(II)) & 3.0 & 79 & 25 \\
DMP (1.0 mM EDTA) & 3.0 & 48 & 13 \\
RBBR & 5.0 & 1 & 13 \\
VA & 5.0 & 3670 & 83 \\
VA & 3.0 & 1500 & 13 \\
ABTS & 5.0 & 5 & 25 \\
ABTS & 3.0 & 5 & 25 \\
\hline
\end{tabular}

Table 3

Specific activity of RBP for the oxidation of selected aromatic substrates

\begin{tabular}{llc}
\hline Substrate & Wavelength $(\mathrm{nm})$ & $\begin{array}{l}\text { Specific activity } \\
\left(\mathrm{IU} \mathrm{mg}^{-1}\right)\end{array}$ \\
\hline Cathecol & 238 & 168 \\
Hydroquinone & 247 & 30 \\
4-Methoxyphenol & 253 & 47 \\
Methylhydroquinone & 250 & 28 \\
p-Aminophenol & 246 & 85 \\
Guaiacol & 456 & 8 \\
Ferulic acid & 310 & 43 \\
$\alpha$-Naftol & 255 & 21 \\
Reactive Black 5 & 598 & 1 \\
\hline
\end{tabular}

${ }^{\mathrm{a}}$ Measured in $100 \mathrm{mM}$ sodium tartrate ( $\left.\mathrm{pH} 3.5\right)$.

oxidise Poly-R 478 (50.00 $\Delta \mathrm{Abs} \mathrm{min}^{-1} \mathrm{mg}^{-1}$ at $\left.420 \mathrm{~nm}\right)$, $o$-anisidin $\left(95.00 \Delta \mathrm{Abs} \mathrm{min}^{-1} \mathrm{mg}^{-1}\right.$ at $\left.460 \mathrm{~nm}\right)$ and $p$ anisidin (70.00 $\Delta \mathrm{Abs} \mathrm{min}^{-1} \mathrm{mg}^{-1}$ at $460 \mathrm{~nm}$ ) in the absence of mediators-although actual activity values were not determined.

The kinetic constants for selected substrates at given $\mathrm{pH}$ values, were duly calculated; the apparent values of $K_{\mathrm{m}}$ and $V_{\text {max }}$, are tabulated in Table 2.

\section{Discussion}

The homogeneous preparation of RBP was a brownish-red solution, hence suggesting the presence of a heme group. The spectral characteristics of RBP are similar to those of typical peroxidases; the Soret band representative of the absorption peak of peroxidases [15] was observed at $407 \mathrm{~nm}$ for the native RBP; the shifts in the smaller peaks observed are also similar to those reported in literature $[15,16]$ for peroxidases containing a protoheme as prosthetic group. The molar extinction coefficient obtained at $407 \mathrm{~nm}$ is of the same magnitude of those reported for ligninolytic peroxidases [15-17]. The absorption spectrum is similar, but not identical to the one reported elsewhere [18] pertaining to a versatile peroxidase from B. adusta which shows a Soret band at $409 \mathrm{~nm}$, and two charge transfer bands at $501 \mathrm{~nm}$ and $632 \mathrm{~nm}$.

It has been suggested that, in $\mathrm{LiP}$ and $\mathrm{MnP}$, the heme iron atom is predominantly in the hexacoordinated high spin state, with a water molecule bound at the sixth coordination position [19]. The similarity of the spectra obtained pertaining to RBP and to those of LiP and MnP made available from other authors [20,21] suggests that the major heme state of RBP is also a hexacoordinated high spin state.

It is usually claimed that changes in absorbance peaks, such as those observed in RBP following addition of hydrogen peroxide, arise because of formation of compound I; however, this transformation of native peroxidase is usually completed with the addition of one molar equivalent of the aforementioned compound [17]. It was also reported [17] for manganese peroxidase from $P$. chrysosporium that the addition of two equivalents of hydrogen peroxide produced compound II, and that the addition of 250 equivalents 
(considered as an excess of hydrogen peroxide) produced compound III. In fact, the amount of such a reagent used in this assay (225 molar equivalents) is very close to this value but the spectrum produced is still similar to that observed for compound II of MnP and HRP [17]. The amount of hydrogen peroxide required, at $\mathrm{pH} 4.5$, to produce $\mathrm{MnP}$ compound III from P. chrysosporium (ca. 250 equivalents) is similar to that required to produce HRP compound III [17], yet much greater than the amount needed to obtain LiP compound I from $P$. chrysosporium (25 equivalents) at $\mathrm{pH} 6.0$ [16]. As the $\mathrm{pH}$ used in the RBP assay was 6.0, this fact might reflect structural and functional differences between $\mathrm{LiP}$ and the RBP versatile enzyme. Differences between RBP and MnPs could in fact arise, partially because of the $\mathrm{pH}$ used in the assay. According to Renganathan and Gold [16], the formation of LiP compounds I and II is strongly influenced by reaction $\mathrm{pH}$-and so this effect might also be present for other peroxidases. The catalytic differences, between RBP and other manganese peroxidases, observed may also help to explain those values. In general, the presence of such too high an excess of hydrogen peroxide (225 molar equivalents) in the absence of a reducing substrate leads to emergence of compound III, both for $\mathrm{LiP}$ and $\mathrm{MnP}$.

The value of $45 \mathrm{kDa}$ estimated for the molecular mass of the enzyme via SDS-polyacrylamide gel electrophoresis is similar to that of the other versatile peroxidases-which, at present, encompasses only Bjerkandera and Pleurotus sp. strains $[1-6,8,9]$; it is also of the same order than the molecular masses of typical ligninolytic peroxidases. Comparison of the $\mathrm{N}$-terminal sequence of the purified RBP enzyme to those of the novel versatile peroxidases-recently described to be produced by other strains $[2,4,5,7,9]$, indicates that the highest degree of similarity is associated with enzymes isolated from Bjerkandera sp., as expected.

With the exception of VA, all substrates tested exhibit apparent $K_{\mathrm{m}}$ values (at one or more of the conditions tested) similar or lower than those found for $\mathrm{Mn}$ (II) oxidation - hence suggesting a high affinity of the RBP for those substrates. This RBP enzyme shows also high affinity for (the oxidising substrate) hydrogen peroxide at $\mathrm{pH} 5.0$, with $K_{\mathrm{m}}$ values ( 3 and $7 \mu \mathrm{M}$ ) much lower than those found for $B$. adusta LiP isoenzymes $(40-60 \mu \mathrm{M})$-but similar to those obtained for the Pleurotus and Bjerkandera spp. versatile peroxidases $[2,3,5,7,9]$.

Comparison of $K_{\mathrm{m}}$ values for the oxidation of $\mathrm{Mn}(\mathrm{II})$ also revealed high similarity with values obtained for the other versatile peroxidases. Smaller values of $K_{\mathrm{m}}$ for DMP oxidation were obtained, as expected, at or near the optimum $\mathrm{pH}$ values (as previously determined) for each condition tested.

The smallest $K_{\mathrm{m}}$ values obtained were for oxidation of RBBR and ABTS ( 1 and $5 \mu \mathrm{M}$, respectively); this fact confirms RBP as a versatile peroxidase with high affinity for dye substrates, e.g. anthraquinone-derived, and high redox compounds, e.g. ABTS (which are substrates usually preferred by plant peroxidases).
Oxidation of VA is favoured at $\mathrm{pH}$ 3.0, as happens with LiP peroxidases, and has an apparent $K_{\mathrm{m}}$ value of $1500 \mu \mathrm{M}$. This value is one half of those reported for other versatile peroxidases (viz. 3000-5330 $\mu \mathrm{M}$ ) [3,5,7,9], with the exception of the MnP-LiP hybrid obtained from Bjerkandera sp. strain BOS55 (viz. 534-116 $\mu \mathrm{M}$ ) [2]. Such small $K_{\mathrm{m}}$ value for VA oxidation is probably the main characteristic that distinguishes this MnP-LiP hybrid peroxidase from others in the same versatile group. The difference found in the $K_{\mathrm{m}}$ values pertaining to VA oxidation suggests that RBP and MnP-LiP hybrid peroxidase could actually be isozymes. Bjerkandera strains might produce more than one different versatile peroxidase, as happens with the two versatile peroxidases already demonstrated to be present on P. eryngii.

\section{Conclusions}

A novel versatile peroxidase (RBP), possessing unique kinetic and spectral characteristics, was isolated and purified from a Bjerkandera strain isolate. This enzyme is able to oxidise manganese, as well as VA and DMP in manganese-independent reactions. Despite the differences found in terms of $K_{\mathrm{m}}$ values, namely for VA oxidation, RBP seems closely related to other versatile peroxidases from strains of the genera Bjerkandera or Pleurotus. However, the differences found between the versatile peroxidases of Bjerkandera strains point for the presence of at least two different versatile peroxidases on this genus, as already found within the Pleurotus genus.

\section{Acknowledgements}

P. Moreira (author) was sponsored by a doctoral fellowship (PRAXIS XXI/BD/15825/98) granted by FCT (Portugal). Partial support, via an FNRS grant (Belgium) for purchase of the AKTA system, is also acknowledged.

\section{References}

[1] Heinfling A, Martinez MJ, Martinez AT, Bergbauer M, Szewzyk U. Transformation of industrial dyes by manganese peroxidases from Bjerkandera adusta and Pleuratus eryngii in a manganeseindependent reaction. Appl Environ Microbiol 1998;64:2788-93.

[2] Mester T, Field JA. Characterization of a novel manganese peroxidase-lignin peroxidase hybrid isozyme produced by Bjerkandera species strain BOS55 in the absence of manganese. J Biol Chem 1998;273:15412-7.

[3] Heinfling A, Ruiz-Duenas FJ, Martinez MJ, Bergbauer M, Szewzyk U, Martinez AT. A study on reducing substrates of manganeseoxidizing peroxidases from Pleurotus eryngii and Bjerkandera adusta. FEBS Lett 1998;428:141-6.

[4] Heinfling A, Martinez MJ, Martinez AT, Bergbauer M, Szewzyk $\mathrm{U}$. Purification and characterization of peroxidases from the dyedecolorizing fungus Bjerkandera adusta. FEMS Microbiol Lett 1998;165:43-50. 
[5] Palma C, Martinez AT, Lema JM, Martinez MJ. Different fungal manganese-oxidizing peroxidases: a comparison between Bjerkandera sp. and Phanerochaete chrysosporium. J Biotechnol 2000;77:235-45.

[6] Camarero S, Ruiz-Duenas FJ, Sarkar S, Martinez MJ, Martinez AT. The cloning of a new peroxidase found in lignocellulose cultures of Pleurotus eryngii and sequence comparison with other fungal peroxidases. FEMS Microbiol Lett 2000;191:37-43.

[7] Camarero S, Sarkar S, Ruiz-Duenas FJ, Martinez MJ, Martinez AT. Description of a versatile peroxidase involved in the natural degradation of lignin that has both manganese peroxidase and lignin peroxidase substrate interaction sites. J Biol Chem 1999;274:10324-30.

[8] Martinez AT. Molecular biology and structure-function of lignin-degrading heme peroxidases. Enzyme Microb Technol 2002;30:425-44.

[9] Ruiz-Duenas FJ, Martinez MJ, Martinez AT. Molecular characterization of a novel peroxidase isolated from the ligninolytic fungus Pleurotus eryngii. Mol Microbiol 1999;31:223-35.

[10] Moreira PR, Almeida-Vara E, Sena-Martins G, Polonia I, Malcata FX, Duarte JC. Decolourisation of Remazol Brilliant Blue $\mathrm{R}$ via a novel Bjerkandera sp. strain. J Biotechnol 2001;89:107-11.

[11] Castillo MD, Stenstrom J, Ander P. Determination of manganese peroxidase activity with 3-methyl-2-benzothiazolinone hydrazone and 3-(dimethylamino) benzoic acid. Anal Biochem 1994;218:399-404.

[12] Mester T, Field JA. Optimization of manganese peroxidase production by the white rot fungus Bjerkandera sp. strain BOS55. FEMS Microbiol Lett 1997;155:161-8.

[13] Linko S, Haapala R. A critical study of lignin peroxidase activity assay by veratryl alcohol oxidation. Biotechnol Tech 1993;7:7580.

[14] Eggert C, Temp U, Dean JFD, Eriksson KEL. A fungal metabolite mediates degradation of non-phenolic lignin structures and synthetic lignin by laccase. FEES Lett 1996;391:144-8.
[15] Kim SJ, Shoda M. Purification and characterization of a novel peroxidase from Geotrichum candidum Dec 1 involved in decolonization of dyes. Appl Environ Microb 1999;65:1029-35.

[16] Renganathan V, Gold MH. Spectral characterization of the oxidized states of lignin peroxidase, an extracellular heme enzyme from the white rot basidiomycete Phanerochaete chrysosporium. Biochemistry 1986;25:1626-31.

[17] Wariishi H, Akileswaran L, Gold MH. Manganese peroxidase from the basidiomycete Phanerochaete chrysosporium - spectral characterization of the oxidized states and the catalytic cycle. Biochemistry 1988;27:5365-70

[18] Aceves MA, Baratto MC, Basosi R, Vazquez-Duhafo R, Pogni R. Spectroscopic characterization of a manganese-lignin peroxidase hybrid isozyme produced by Bjerkandera adusta in the absence of manganese: Evidence of a protein centred radical by hydrogen peroxide. J Mol Catal B-Enzym 2001;16:159-67.

[19] Smulevich G. Understanding heme cavity structure of peroxidases. comparison of electronic absorption and resonance Raman spectra with crystallographic results. Biospectroscopy 1998;4:S3-17.

[20] Poulos TL, Patterson WR, Sundaramoorthy M. The crystal-structure of ascorbate and manganese peroxidases - the role of nonheme metal in the catalytic mechanism. Biochem Soc Trans 1995;23:228-32.

[21] Smulevich G, Neri F, Marzocchi MP, Welinder KG. Versatility of heme coordination demonstrated in a fungal peroxidase. Absorption and resonance Raman studies of Coprinus cinereus peroxidase and the Asp245 $\rightarrow$ Asn mutant at various $\mathrm{pH}$ values. Biochemistry 1996;35:10576-85.

[22] Wang YX, Vazquez-Duhalt R, Pickard MA. Purification, characterization, and chemical modification of manganese peroxidase from Bjerkandera adusta UAMH 8258. Curr Microbiol 2002;45:77-87.

[23] Giardina P, Palmieri G, Fontanella B, Rivieccio V, Sannia G. Manganese peroxidase isoenzymes produced by Pleurotus ostreatus grown on wood sawdust. Arch Biochem Biophys 2000;376:171-9. 